\title{
Initial Establishment of Four Species on a Mine Spoils
}

\author{
JERRY L. HOLECHEK
}

\begin{abstract}
Research was conducted in a greenhouse at Bozeman, Montana, and on coal mine spoils at Colstrip, Mont., in 1975 to determine the initial establishment of fairway crested wheatgrass (A gropyron cristatum), critana thickspike wheatgrass (Agropyron dasystachyum), ranger alfalfa (Medicago sativa), and fourwing saltbush (Atriplex canescens). Establishment of the four species in the greenhouse experiment was different from that in the field experiment. In both studies all four species showed good initial establishment. Nitrogen and phosphorus fertilizer application after emergence had no effect on the survival of any species.
\end{abstract}

Increased strip mining of coal in the Northern Great Plains will take several thousand acres of rangeland temporarily out of production during the next decade. After mining, it is desirable to establish quickly a permanent vegetational cover that will reduce soil erosion, provide wildlife habitat, and support other land uses. Certain species may be superior to others in fulfilling these requirements. The objectives of this study were to determine the germination and initial survival of critana thickspike wheatgrass (Agropyron dasystachyum), fairway crested wheatgrass (Agropyron cristatum), ranger alfalfa (Medicago sativa) and fourwing saltbush (Atriplex canescens) when subjected to controlled conditions in a greenhouse and when planted on strip mine spoils at Colstrip, Mont. Critana thickspike wheatgrass and fourwing saltbush are species native to the Colstrip area.

\section{Methods}

A representative sample of surface topsoil material was taken from strip mine spoils at Colstrip, Mont., and transported to a greenhouse owned by Montana State University at Bozeman, Mont., in late winter of 1975 . Approximately $88 \mathrm{~kg}$ of soil material was weighed and placed in each of 24 rectangular frames on greenhouse benches. Fourwing saltbush, critana thickspike wheatgrass, ranger alfalfa, and fairway crested wheatgrass were randomly assigned to the experimental units. This resulted in six replications of each species in a completely randomized design. Experimental units were seeded on the basis of pure live seed $/ \mathrm{m}^{2}$ on March 22. All seed used in the study had been recently tested for germination. Fourwing saltbush seed was dewinged. Crested wheatgrass, thickspike wheatgrass, and ranger alfalfa were broadcast seeded at 538 pure live seeds $/ \mathrm{m}^{2}$. This seeding rate was used to compensate for the uneven depth of broadcast seeding (Vallentine 1971). Seeds were incorporated into the soil material by a hand cultipacker. Fourwing saltbush was seeded at a reduced rate (108

\footnotetext{
Author was graduate assistant, Department of Animal and Range Sciences, Montana State University, Bozeman, Montana. Jerry L. Holechek is currently assistant professor of range ecology, Department of Animal and Range Sciences, New Mexico State University, Las Cruces, New Mexico 88003.

This article is Journal Series No. 869, Montana Agricultural Experiment Station, Bozeman, Montana. The research was funded by the U.S. Forest Service Surface Environment and Mining (SEAM) Program and was part of Cooperative Agreement No. 16 (USC 581; 581a-581i).

Manuscript received October 1, 1979.
}

pure live seeds $/ \mathrm{m}^{2}$ ) to lower intraspecific competition. Water and temperature were cont rolled so that average conditions at Colstrip, Mont., for each were approximated. Nitrogen and phosphorus fertilizer was randomly applied to one half the experimental units seeded to each species immediately after emergence. The rates of application were $37 \mathrm{~kg} / \mathrm{ha}$ of nitrogen and $94 \mathrm{~kg} / \mathrm{ha}$ of phosphorus.

During the same period 24 experimental units, $9 \times 10 \mathrm{~m}$, were established on strip mine spoils at Colstrip, Mont., that had been previously ripped and topsoiled. The study was set up with three blocks of eight experimental units. The four species were randomly assigned to each block. Seeding was accomplished by broadcasting and then cultipacking on April 4. The same seeding rates were used as in the greenhouse study. Nitrogen and phosphorus fertilizer were applied at the same rate used in the greenhouse study. In 1975, the total precipitation at Colstrip was $44 \mathrm{~cm}$. Precipitation during the growing season was $7 \%$ above average. Data concerning the physical and chemical characteristics of the soil material on the study area were given by Holecheck (1976).

In the greenhouse study, plant density was evaluated on April 20 and again on July 1. All plants were counted in each experimental unit. Plant density data were collected for the field study on June 8 and August 15 using $20 \times 20 \mathrm{~cm}$ square frames. Three transects were randomly selected for sampling, and seven seedling counts were taken at $1-\mathrm{m}$ intervals on each transect for a total of 21 subsamples per experimental unit. Data concerning the above- and belowground biomass of the four species in the greenhouse and field experiments were also collected and reported by Holechek (1980).

Analysis of variance was used to compare differences between critana thickspike and fairway crested wheatgrass on fertilized and unfertilized experimental units in both the field and greenhouse experiments. Differences in plant density between emergence and survival at the end of the growing season, and between fertilized and unfertilized experimental units for ranger alfalfa and fourwing saltbush were determined with the standard $t$-test. The procedures of Steel and Torrie (1960) were used for all statistical tests.

\section{Results and Discussion}

Results obtained from the greenhouse and field studies are reported in Table 1. Emergence and survival data were different in the greenhouse compared to the field experiment. Environmental conditions in the greenhouse were much more different from those in the field. This same kind of difference exists in environmental conditions between years. For this reason, data concerning plant establishment during a particular year must be interpreted with considerable caution. This study also shows the danger of applying greenhouse data to conditions existing in the field.

Nitrogen and phosphorus fertilizer application had no effect on 
Table 1. Seedling germination (\%) and survival $(\%)$ in the greenhouse and field experiments.

\begin{tabular}{|c|c|c|c|c|c|}
\hline \multirow[b]{3}{*}{ Greenhouse } & \multirow{2}{*}{ April 20} & \multicolumn{2}{|c|}{ July 1} & \multirow{3}{*}{ Germination } & \multirow{3}{*}{ Survival } \\
\hline & & \multirow{2}{*}{$\begin{array}{l}\text { Fertilized } \\
\text { plants } / \mathrm{m}^{2}\end{array}$} & \multirow{2}{*}{$\begin{array}{l}\text { Unfertilized } \\
\text { plants } / \mathrm{m}^{2}\end{array}$} & & \\
\hline & Plants $/ \mathrm{m}^{2}$ & & & & \\
\hline Critana thickspike wheatgrass & 366 & 350 & 338 & 68 & 99 \\
\hline Fairway crested wheatgrass & 409 & 344 & 348 & 76 & 85 \\
\hline Ranger alfalfa & 296 & 237 & 255 & 55 & 83 \\
\hline Fourwing saltbush & 99 & 95 & 105 & 92 & 101 \\
\hline Field & June 8 & August 15 & & & \\
\hline Critana thickspike wheatgrass & 312 & 244 & 254 & 58 & 80 \\
\hline Fairway crested wheatgrass & 259 & 212 & 208 & 48 & 81 \\
\hline Ranger alfalfa & 257 & 220 & 234 & 48 & 88 \\
\hline Fourwing saltbush & 48 & 42 & 46 & 44 & 93 \\
\hline
\end{tabular}

survival of any species in either experiment. Other investigators have reported these two fertilizers did not improve grass establishment (Hull 1963, Cook 1965, Bryan and Murphy 1968, Farmer et al. 1974). Generally, phosphorus has increased legume seedling survival while nitrogen has given negative results (Brouse and Burzlaff 1968, Holland et al. 1969). The effect of nitrogen and phosphorus application on shrub establishment has not been well investigated.

Emergence and initial survival of the four species used in this experiment were high. Only fairway crested wheatgrass in the greenhouse suffered significant $(P<.01)$ mortality between emergence and termination of the experiment. During the latter part of this period, plants in both the field and greenhouse studies had reduced soil moisture levels. However, moisture stress was not evaluated.

Data from this study concerning the initial establishment of crested wheatgrass and ranger alfalfa agree closely with other investigations. Considerable information is available showing that fairway crested wheatgrass has high emergence and survival under a variety of weather and site conditions on the Northern Great Plains (Lodge 1972, Wilson et al. 1970, Wilson 1973, Sindelar et al. 1974, Depuit and Coenenberg 1979). Ranger alfalfa has also given good germination and establishment on both rangelands and mine spoils on the Northern Great Plains (Barnes and Nelson 1950, Campbell 1963, Kilcher and Heinrichs 1965, Depuit et al. 1978).

Other research concerning the initial establishment of thickspike wheatgrass is restricted to a mine spoils investigation at Colstrip, Mont., conducted by Buchholz (1972). He reported this species had high emergence and first-year survival. Depuit and Coenenberg (1979) reported information suggesting good long-term survival of critana thickspike wheatgrass on mine spoils at Colstrip.

In addition to the present investigation, other investigations are available showing good establishment of fourwing saltbush on mine spoils in the Northern Great Plains (Dolloph and Majerus 1975, Holechek 1979, Depuit and Dollhoph 1978, Depuit et al. 1978). Fourwing saltbush has been easy to establish in the Great Basin, which is similar in some respects to the Northern Great Plains (Plummer et al. 1966). Fourwing saltbush does not have the complicated germination requirements associated with many other shrub species (Springfield 1964, 1966).

In conclusion, the four species used in this investigation showed good initial establishment in both the greenhouse and field studies. Nitrogen and phosphorus fertilizer application had no effect on initial survival in either study. If it is desired to emphasize native species in mine spoils planting on the Northern Great Plains, critana thickspike wheatgrass and fourwing saltbush show much potential.

\section{Literature Cited}

Barnes, O.K., A.L. Nelson. 1950. Dryland pastures for the Great Plains. Wyoming Agr. Exp. Sta. Bull. 302.39 p.

Brouse, E.M., and D.F. Burzlaff. 1968. Fertilizers and legumes on subirrigated meadows. Nebraska Agr. Exp. Sta. Bull. 501.65 p.
Bryan, G.G., and W.E. Murphy. 1968. Competition and fertilization as influences on grass seedlings. J. Range Manage. 21: 98-101.

Buchholz, J. 1972. Some effects of fertilization on revegetation of coal mine spoils in southeastern Montana. Unpublished M.S Thesis. Montana State Univ., Bozeman. 92 p.

Campbell, J.B. 1963. Grass-alfalfa versus grass-alone pastures grazed in a repeated-season pattern. J. Range Manage. 16: 78-81.

Cook, C.W. 1965. Plant and livestock responses to fertilized rangelands. Utah Agr. Exp. Sta. Bull. 455. 63 p.

Depuit, E.J., and D.J. Dollhoph. 1975. Revegetation research on coal surface-mined lands at West Decker Minc, Decker, Montana. Montana Agr. Exp. Res. Rep. 150. Montana State Univ. Bozeman. 81 p.

Depuit, E.J., J.G. Coenenberg, and W.W. Wilmuth. 1978. Research on revegetation of surface mined lands. Montana Agr. Exp. Sta. Res. Rep. 127. Montana State Univ., Bozeman. 165 p.

Depuit, E.J., and J.G. Coenenberg. 1979. Responses of revegetated coal strip mine spoils to variable fertilizer rates, longevity of fertilization program and season of seeding. Montana Agr. Exp. Sta. Res. Rep. 133. Montana State Univ., Bozeman. 30 p.

Dollhoph, D.J., and M.E. Majerus. 1975. Strip mine reclamation research at Decker, Montana. Montana Agr. Exp. Sta. Res. Rep. 83. Montana State Univ., Bozeman. 42 p.

Farmer, E.E., R.W. Brown, B.E. Richardson, and P.R. Packer. 1974, Revegetation research on the Decker coal mine in southeastern Montana. U.S. Dep. Agr. Forest Serv. Res. INF-162, 12 p.

Holecheck, Jerry L. 1976. Initial effects of different species treatments and fertilizer rates on a mine spoils rehabilitation. Unpublished Thesis. Montana State Univ., Bozeman. 91 p.

Holecheck, Jerry L. 1979. Fertilizer effects on initial plant establishment on a mine spoils rehabilitation. Abst. of 32nd Annual Meeting. Soc. for Range Manage. p. 46.

Holechek, Jerry L. 1980. Fertilizer effects on above- and belowground biomass of four species. J. Range Manage. (in press).

Holland, A.A., J.E. Street, and W.A. Williams. 1969. Range legume inoculation and nitrogen fixation by root-nodule bacteria. J. Range Manage. 19: 71-74.

Hull, A.C. Jr. 1963. Fertilization of seeded grasses on mountainous rangelands in northeastern Utah and southeastern Idaho. J. Range Manage. 16: 306-310.

Kilcher, M.R., and D.H. Heinrichs. 1965. Performance of some grassalfalfa mixtures in southwestern Saskatchewan during drought years. Canadian J. Plant Sci. 46: 279-284.

Lodge, R.W., S. Smoliak and A. Johnston. 1972. Managing crested wheatgrass pastures. Canada Dep. Agr. Publ. 1493. 54 p.

Plummer, P.A., S.B. Monsen, and D.R. Christensen. 1966. Fourwing saltbush, a shrub for future game ranges. Utah Fish \& Game Dep. Pub. 66-4 $12 \mathrm{p}$.

Sindelar, B.W., R. Atkinson, M. Majerus, and K. Proctor. 1974. Surface mined land reclamation research at Colstrip, Montana. Res. Rep. 69. Mont. Agr. Exp. Sta., Montana State University, Bozeman. 98 p.

Springfield, H.W. 1964. Factors affecting germination of fourwing saltbush. U.S. Dep. Agr. Forest Serv. Res. Note RM-25.

Springifield, H.W. 1966. Germination of fourwing saltbush seeds at different levels of moisture stress. Agron. J. 58: 149-150.

Steel, R.G. and J.H. Torrie. 1960. Principles and Procedures of Statistics. McGraw-Hill Book Co., New York. 532 p.

Vallentine, J.F. 1971. Range Development and Improvements. Brigham Young University Press, Provo, Utah. 515 p. 